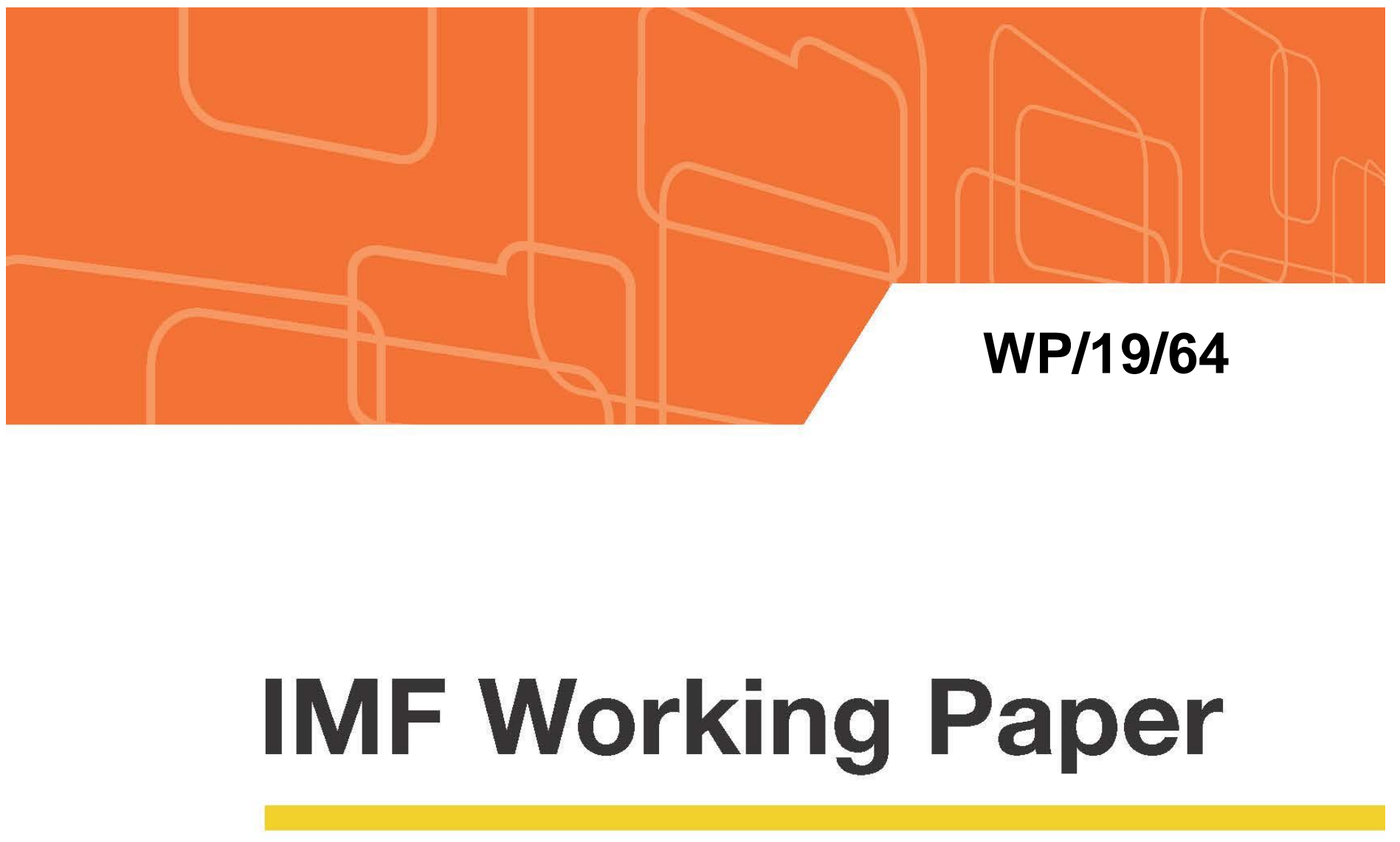

\title{
Self-Employment and Support for The Dutch Pension Reform
}

by Izabela Karpowicz

IMF Working Papers describe research in progress by the author(s) and are published to elicit comments and to encourage debate. The views expressed in IMF Working Papers are those of the author(s) and do not necessarily represent the views of the IMF, its Executive Board, or IMF management.

$$
\text { I N T E R N A T I O N A L M O N E T A R Y F U N D }
$$




\title{
IMF Working Paper
}

European Department

\section{Self-Employment and Support for The Dutch Pension Reform Prepared by Izabela Karpowicz ${ }^{1}$}

Authorized for distribution by Thomas Dorsey

March 2019

\section{IMF Working Papers describe research in progress by the author(s) and are published to elicit comments and to encourage debate. The views expressed in IMF Working Papers are those of the author(s) and do not necessarily represent the views of the IMF, its Executive Board, or IMF management.}

\begin{abstract}
The Netherlands' pension system is characterized by high participation rates, adequate retirement income, strong capitalization and sustainability. Pressure points are arising, however, due to population aging and untransparent intergenerational transfers inherent in the system. Moreover, the Dutch pension system needs to adapt to the changing labor market landscape with an increasing share of workers in self-employment not covered by any pension arrangement. The government has proposed replacing collective definedbenefits schemes with personal accounts, and abolishing uniform premia and constant accrual rates. The micro-data analysis shows that allowing greater risk-taking and freedom of choice in managing pension savings could crowd self-employed into pension schemes.
\end{abstract}

JEL Classification Numbers: J21, J41, H55

Keywords: pension reform, self-employment

Author's E-Mail Address: ikarpowicz@imf.org

\footnotetext{
${ }^{1}$ For useful comments on this paper I wish to thank Enrica Detragiache, Maurice Doll, Thomas Dorsey, Csaba Feher, Armand Foujieu, Mauro Mastrogiacomo, Carlos Mulas-Granados, Jordy Huis, Jante Parlevliet, Mauricio Soto, and the participants of the seminar at De Netherlandische Bank in Amsterdam.
} 
TABLE OF CONTENTS

PAGE

ABSTRACT __________ 2

I. INTRODUCTION ______ 4

II. BACKGROUND ON THE PENSION REFORM AND POLITICAL ECONOMY ___ 5

III. SELF-EMPLOYMENT AND PENSION REFORM SUPPORT ___ 9

IV. MODEL ESTIMATIONS ____ 13

A. Stylized Facts

B. Regression Results __ 16

V. CONCLUSIONS__ 18

VI. REFERENCES _ 19

\section{FIGURES}

1. Composition of Self-Employment, 2008-17 _ 10

2. Composition of Self-Employed Jobs, 2017

3. Self-Employed Education and Income, 2017

4. Answers to Questions on Pension Preferences, 2017 __ 13

5. Psychological Traits, $2017 \ldots$

\section{APPENDICES}

I. Data and Tables

II. The DNB Households Survey (DHS) 


\section{INTRODUCTION}

The Netherlands' proposed pension reform is under discussion in the context of a system that has been regarded in the literature as one of the most sophisticated. According to the Melbourne Mercer Global Pension Index 2018, the Dutch pension system ranked first in a group of 34 countries, on a scale evaluating adequacy of benefits and the system's sustainability and financial integrity across 40 indicators. The pension system is viewed as having achieved high participation rates, provided adequate retirement income, and ensured sustainability through a model that adroitly takes advantage of the strengths intrinsic in defined-benefit (DB) and defined-contributions (DC) frameworks. However, pressure points are arising because of population aging, low long-term interest rates, and changes in the labor market structure that have strained redistribution, bringing to the fore intergenerational tensions. In 2014, the government initiated a series of consultations with social partners on a possible reform. The coalition agreement of 2017 proposed a route for reform, and the agreement with social partners was expected in early 2018 with legislation to be passed in 2020. While there appears to be a broad consensus on the need for reform, an agreement on the final package has been delayed.

In this chapter, we analyze pension system preferences and self-employment. Facilitated by favorable tax treatment, self-employment has increased in recent years and is now among the highest in Europe. A further switch of younger generations to self-employment could, however, put substantial pressure on the long-term solvency of the collective schemes (Gerard, 2019) and represents a risk of termination of the social contract. Building on the work on Parlevliet (2018) who analyzed public acceptance of the increase in retirement age in Netherlands in 2012, this paper examines individuals' pension system preferences and their choice of labor contract.

Support for specific pension system characteristics is significantly associated with selfemployment status. We find that, after controlling for demographic characteristics and individual psychological traits, individuals who have a preference for pension plans with

more freedom of choice and more investment risk are significantly more likely to choose self-employment than regular employment under the current pension system. A pension reform giving more freedom of choice to regular employees should reduce incentives to go into self-employment and include individuals who do not enjoy pension coverage into personal savings schemes. These issues are central to the debate in Netherlands not only in the context of social insurance but also in the context of the dual labor market.

The rest of the paper is organized as follows. Section B provides a background on the pension reform; section $\mathrm{C}$ describes the self-employed population based on household survey data; section D presents the model and estimation results; and section E concludes. 


\section{Background on the Pension Reform And Political Economy}

The Dutch pension system has three pillars. The $1^{\text {st }}$ pillar - public, pay-as-you go - benefit, grants a minimum flat pension to the entire population subject to age and residency requirements (see Table 1, Appendix I). The $2^{\text {nd }}$ pillar occupational schemes are the predominant type of pension contracts covering over 90 percent of all employees and providing supplementary benefits based on lifetime wages. The $3^{\text {rd }}$ pillar pension schemes are voluntary, tax-exempt contracts. Participation in $3^{\text {rd }}$ pillar is still limited, contributing to about 10 percent of pension systems' assets, but growing.

The $2^{\text {nd }}$ pillar Dutch occupational schemes are known for having combined the features of the DB and DC schemes.

- Contributions are quasi-mandatory and derived from collective labor agreements. Contributions are levied at a uniform rate, independent of age. The rates can be increased in the case the pension fund falls below the target solvency ratio but have de facto been fix.

- Benefits are accrued annually at a maximum rate of 1.875 percent, providing 75 percent of average lifetime pay after 40 years of contributions. However, in contrast with pure DB schemes, Dutch DB contracts are structured as deferred variable annuities accumulated through an investment strategy that targets a stable lifetime income. This makes the system a de facto "hybrid DB" that displays some features of the DC scheme inasmuch as the final benefit can (and does) change over time. Annuities are indexed to wages or inflation but can be frozen or cut in nominal terms conditional on the funding rate.

- $\quad 2^{\text {nd }}$ pillar funds are managed by boards consisting of employers, unions, retirees, and independent specialists who act as fiduciary trustees and determine investments, contribution levels, and indexation collectively (Bovenberg and Nijman, 2017). The outcomes of such decision-making result in solutions that are rooted in a strong consensus.

The advantages of this design are multiple and include high pension coverage, risk pooling and risk sharing, and long-term sustainability of pension funds. Over a 10-year horizon (established prudentially) the system is self-sustainable given the possibility (and the obligation) of the funds to address the eventual funding shortfall through changes in revenues (contributions), accrual of benefits, as well as payment of earned annuities. ${ }^{2}$ In this respect, the Dutch occupational schemes resemble a DB scheme, in which decisions are made

\footnotetext{
${ }^{2}$ However, pension funds have used overly optimistic assumptions about expected returns which allowed them to circumvent nominal cuts (Wills Tower Watson, 2018; and DNBulletin 2017). The pension funds are required to meet a funding ratio in excess of 110 percent. Pension funds' financial positions have been improving in recent years as favorable developments in the equity and foreign exchange markets have been offsetting the negative consequences of the decline in interest rates. The funding ratio was 108.4 percent in mid-2018, against the statutory minimum of 104.2 percent (DNB, June 2018).
} 
collectively and affect all beneficiaries, current and future ones, while at the same time avoiding underfunding, as in a DC plan. Aside from ensuring sustainability, collective management of savings lessens concerns stemming from cognitive constraints and financial illiteracy and strengthens participants bargaining power in financial markets. Pooling of longevity and systemic macro risks is also a desirable feature that makes the system closer to a pure DB.

However, characteristics that make the Dutch pension system attractive also govern some of its disadvantages that have led to increasing complexity and opacity of transfers. Uniform accrual rates imply an intergenerational transfer from the young to the old, by virtue of the time value of money, and from the lower educated to the higher educated. This implicit subsidy is, however, partly offset by the reverse redistribution because rights accumulated in the past at higher real return rates are subsidizing annuities which are valued the risk-free rate (Bovenberg and Nijman, 2017). In addition, the indirect link between changes in contributions and benefits stemming from changes in macro environment and the flow of new entrants into the system have increased uncertainty. The system has become complex and, as investment risks are increasingly born by participants, it becomes even more important that allocation of losses and gains across individuals and generations are transparent. Finally, given the governance structure of pensions funds, agreement on any potential reform is more difficult and must satisfy multiple, and at times conflicting, interests.

The pension reform in the coalition agreement proposes to replace variable annuities, characteristic of the Dutch "hybrid DBs", with personal entitlements in the form of financial assets, akin to a DC. Moreover, the new system would feature insurance contracts, hedging participants against longevity risk, and possibly also collective buffers that allow for sharing systemic risks across generations. These solutions that have become known in the literature as "third space" or "personal pensions with risk-sharing and collective buffers" (PPR-CB), seek to produce a more predictable income stream for participants by means of a collective approach to investment and decumulation, thus minimizing inefficiencies related to the higher cost of investment. The PPR-CB offer the possibility to tailor financial instruments to individual risk preferences more closely while still targeting a desired retirement income stream. The PPR-CB would improve the system's transparency, at least the PPR part would do so and, more importantly, the reform would shift to participants virtually all risks related to pensions that may currently be borne by employers.

As the Netherlands' pension system appears sound and sustainable it is justified to raise the question - is this the right time for reform? Given absence of apparent sustainability pressures, pension reform was not seen as top priority for the government in a survey conducted by the European Commission in 2018. Among the economic objectives for the government a significantly greater share of respondents prioritized health, social security and housing issues. Fewer people in Netherlands today see pension reform as a national priority compared with the past, although a higher share of individuals still sees pension income as 
one of important personal preoccupations, albeit less so than in 2016. Why is then the pension reform necessary? Who supports it and who gains from it?

Public Opinion of Important Issues Facing the Netherlands 2018

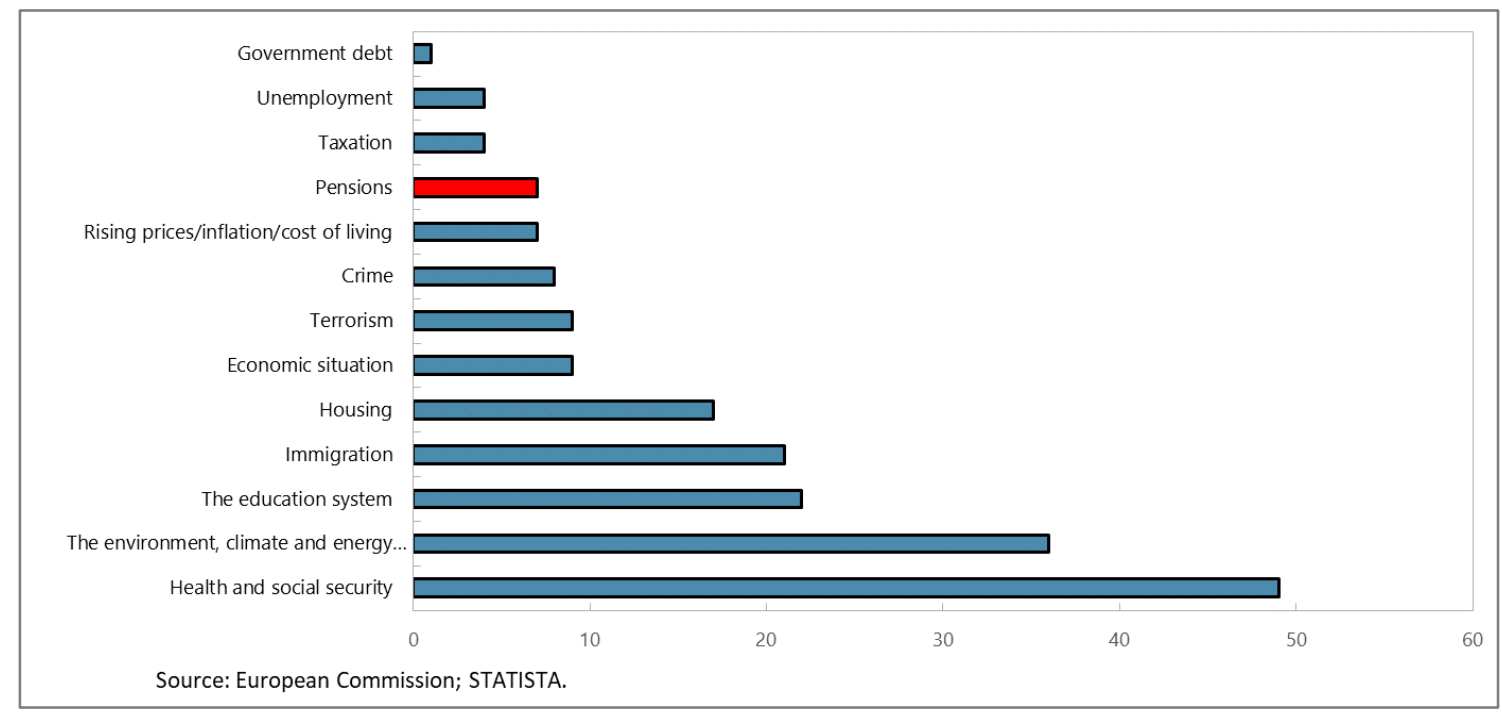

The government views the reform as necessary because of revealed tensions surrounding intergenerational risk transfers and the systems' inadequacy in supporting the needs of the changing labor market. Population aging is putting pressure on DB pension schemes, including in Netherlands, and making the transfer from young to old employees less viable. Moreover, transitional labor markets of today, in which contributions histories are occasionally erratic and incomplete, imply that risk sharing may be costlier and no longer the preferred social choice. ${ }^{3}$ This argument could be a much more prominent driver of change compared with other justifications, including the preference towards managing risks individually for which evidence is not clear cut, as van Dalen and Henkens (2017) show. Although

Two Priorities Identified by Respondents (Percent of total)

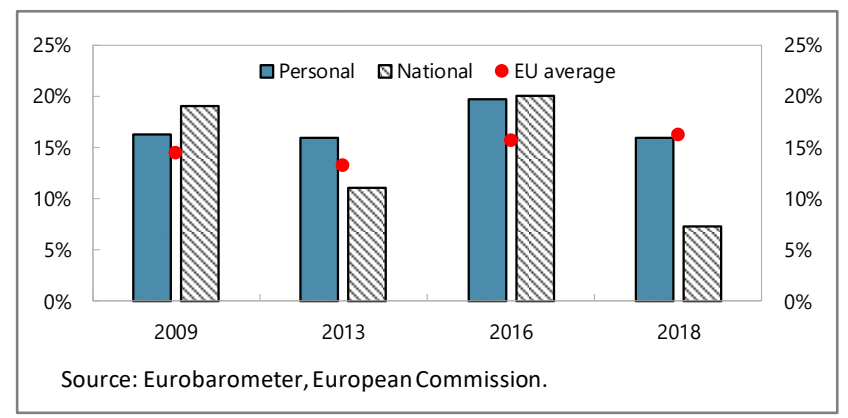
individuals already bear the risks of lower retirement income through the possibility of benefit cuts, from the perspective of the government, offloading fiscal risks to individuals more explicitly may also seem an attractive option. The government has promised to provide support for ensuring a smooth and evenly distributed transition for all age cohorts and participants through tax instruments.

\footnotetext{
${ }^{3}$ On the contrary, the actuarial fairness principle, on the opposite of the range of social contracts, may be the only viable solution to this change.
} 
Employers federations' interests are aligned with government's objectives. Employers' interests mandate that risks related to fluctuations in contributions and liabilities be shifted off their balance sheets which would be achieved in the current proposal. This would lower uncertainty and facilitate investment planning and hiring, which could push up growth over time and ultimately improve pension system sustainability. Introducing regressive premiums, which would vary depending on a contributor's age, would lower the cost and facilitate hiring of younger workers and possibly crowd some self-employed into the pension system. Slowing down the increase the retirement age in the $1^{\text {st }}$ pillar, however, a proposal put forward by the unions in recent negotiation rounds, would also be beneficial for some companies that find older workers expensive and more difficult to retrain. In a survey of 68 companies in 2017, the majority of employers have recognized their responsibility and willingness to assist employees in choosing options that better fit their needs, actively help them manage their pension contributions, and provide support with investment and planning decisions (Wills Towers Watson, 2017).

On the other side of the consultation process spectrum, the labor unions favor redistribution. The unions would support a system that allows more risk sharing across generations. This is because the unions have to strike an internal balance between the interests of the young and those of the retired who retain the membership in pension funds (Ponds and van Riel, 2007). ${ }^{4}$ The unions insist on participation in collective buffers being made mandatory at industry level, to strengthen the bargaining power of pension participants in negotiations with the financial sector. In addition, self-employed should also be forced to participate in the system which would improve its capitalization and protect them from old-age poverty. They would, moreover, favor the possibility of allowing financial buffers of funds to turn negative in the downturn of the economic cycle and avoid curtailing benefits, an idea strongly opposed by the central bank. Related to that, an important point of contention is their insistence on using a stable (higher) ultimate forward rate by funds in their solvency calculation. The unions insist on an arrangement where older generations affected negatively by the transition would be compensated, which would be necessary in a transition from accrual based on average pensions to accrual dependent on age, i.e., lower for older contributors (Preesman, 2017). ${ }^{5}$ More recently, the decision to increase the minimum retirement age for $1^{\text {st }}$ pillar pension benefits to 67 by 2021 and link it 1-to-1 to life expectancy thereafter agreed upon in 2012 was challenged as overly punitive for workers employed in precarious occupations.

From this point on, understanding how individuals view the pension system provides additional insight for evaluating reform support comprehensively and is also helpful in predicting how the different incentives inherent in the system could affect occupational

\footnotetext{
${ }^{4}$ Union representatives on pension boards are also engaged in wage negotiations, thus, the wage and pension policies are closely linked and redistribution across generations is achieved by means of both policy tools.

5 The estimated cost of this compensation is 55 billion euros.
} 
choices and system participation. The following sections will shed more light on selfemployment and its relationship with pensions.

\section{SELf-EmPloyment ANd PENSION REFORM SUPPORT}

In contrast with trends in most other OECD countries, self-employment in the Netherlands has increased over the past decade. The share of self-employment in total employment has picked up by more than 4 percentage points between 2005 and 2017 when it stood at 15.7 percent. The largest increase was recorded in the category "own-account workers" which accounted for 11.6 percent of employed in 2017. In contrast to business owners, own-account workers typically do not employ other individuals (OECD, 2018). Older workers are more represented among the self-employed, with about 40 percent belonging to the age group 5064 , and slightly more than one in three self-employed workers are women. While selfemployment is widespread across all occupations, half of self-employed in 2017 were active in four main categoties: construction, trade, social work and professional, scientific and technical activities. In recent years, the share of self-employed workers with tertiary education has expanded (Figure 1).

Self-employment offers advantages for workers and employers and contributes to labor market flexibility. Self-employment is often motivated by the prospects of lowering the individual tax burden. Indeed, self-employed do not contribute to the sickness and disability insurance and tax deductions are also available for incentivizing entrepreneurship (Dekker and others, 2018). Self-employed on average pay 20 percent lower taxes on equivalent gross income compared to employees (Bosch and others, 2015). Moreover, the cap on tax deduction for contributions in $3^{\text {rd }}$ pillar DC schemes increases with age. Self-employment is attractive for both young workers, who need to gain work experience, and old workers, who have built up sufficient pension capital but would like to remain marginally attached to work. Work arrangements of these individuals are more flexible and more cost-competitive than for regular employees (IMF 2018) which contributes to job satisfaction (Josten and others, 2014) as their primary motive for choosing these contracts is autonomy (Conen and Schippers, 2017). However, these arrangements undermine the level playing field in the labor market, expose the government to revenue loss, and subject self-employed to risks, such as unstable contractual relationships and possible income loss. With only few exceptions, the selfemployed are not covered by sectoral or occupational $2^{\text {nd }}$ pillar arrangements (Mastrogiacomo and others, 2016).

Are self-employed risk attitudes and preference for freedom of choice at the core of their employment status? How likely is that, given certain demographic characteristics, education profiles, and psychological traits individuals opt for self-employment as a result of their preferences for greater risk-taking and freedom of choice in managing pension savings? Answering this question is key to understanding how their behavior may change in response to the reform. On the one hand, it is possible that workers who have built up sufficient savings, such as older workers, or have other sources of income, are not interested in additional risk-sharing. It is also possible, however, that individuals who do not perceive the 
current system as sustainable in the long term prefer financing their old age income in different ways, for instance by investing in individualized $3^{\text {rd }}$ pillar schemes. It could also be the case that the current intergenerational risk transfer is not in their favor. These individuals may welcome the reform and would possibly be willing to transition into contractual arrangement within the same occupations. We attempt to understand the role of the pension system in ensuring a level-playing field in the labor market using evidence from the Dutch National Bank household survey (DHS).

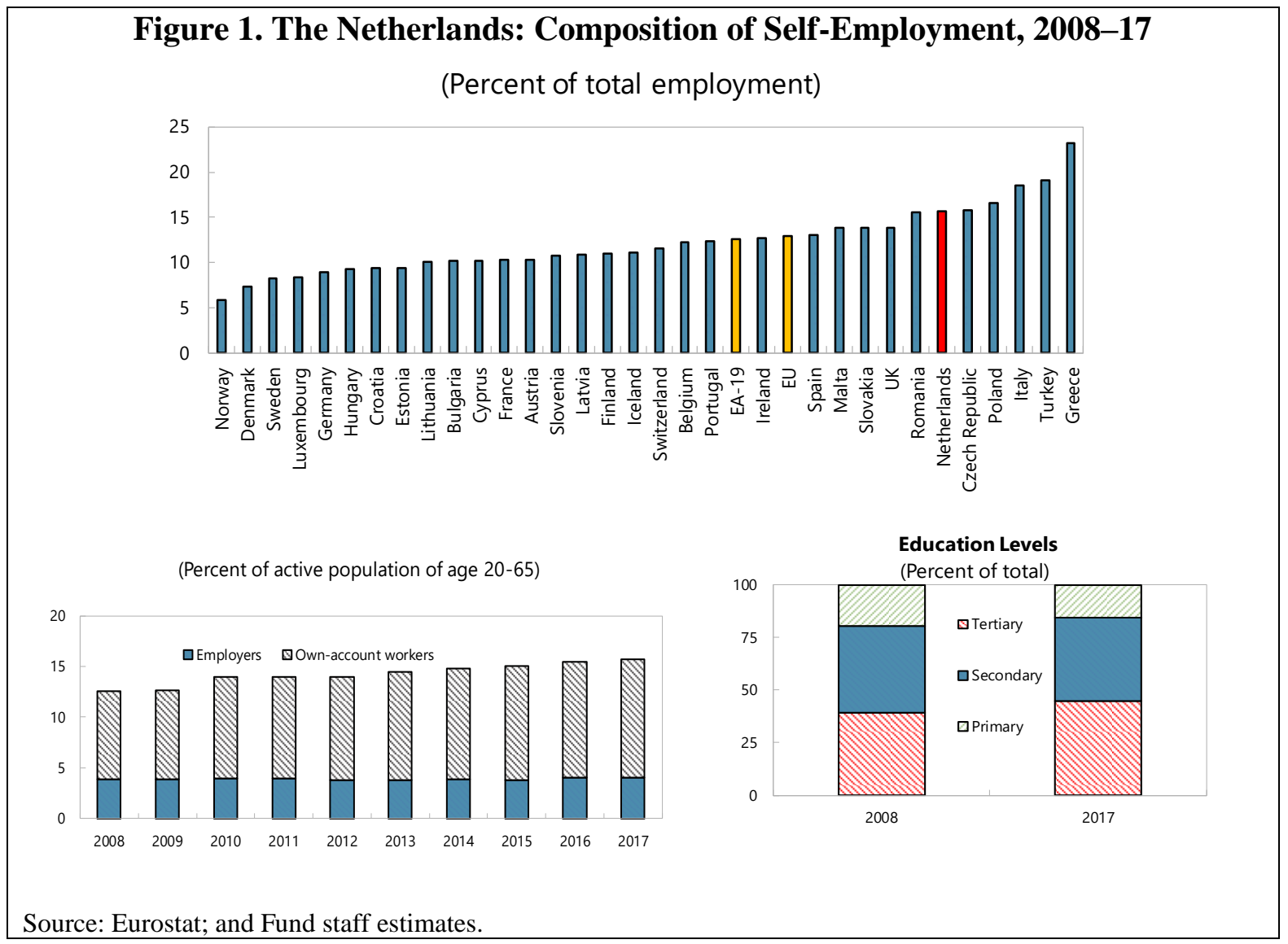

\section{Evidence From the DHS}

The DHS is administered annually to about two thousand Dutch households (five thousand individuals) and includes key questions necessary for understanding risk and choice preferences of the Dutch population. The first survey was conducted in 1993. The objective of the survey it to establish the economic and psychological determinants of households' saving behaviors. The latest wave (the 25 th wave) of the survey was conducted over the period April-October 2017. The survey consists of six questionnaires which comprise general information on the household and individuals, including health status, work patterns, income (including from retirement and benefits), wealth data, other demographic, economic and psychological concepts. Questions included gauge the risk sharing preferences of respondents, preference for choosing the investment profile savings individually, and various 
options available for meeting the possible shortfall in retirement income and pension system sustainability risks. ${ }^{6}$

The self-employed in the DHS exhibits similar characteristics to those reported in official statistics from Eurostat. Two thirds of the approximately 2,000 respondents broadly falling into the labor force category has a paid job. The share of self-employed with a paid job in total self-employed population is lower, at 63 percent (Figure 2). The so-called "selfemployed and freelancers" constitute the overwhelming majority of this group, with individuals owning a family business accounting for less than 9 percent of total. The age and gender group compositions in the survey are in line with that observed for the total labor force, with slightly fewer female workers represented in the self-employed. These features have remained broadly constant over the past several years.

Figure 2. The Netherlands: Composition of Self-Employed Jobs, 2017 (Percent of total)
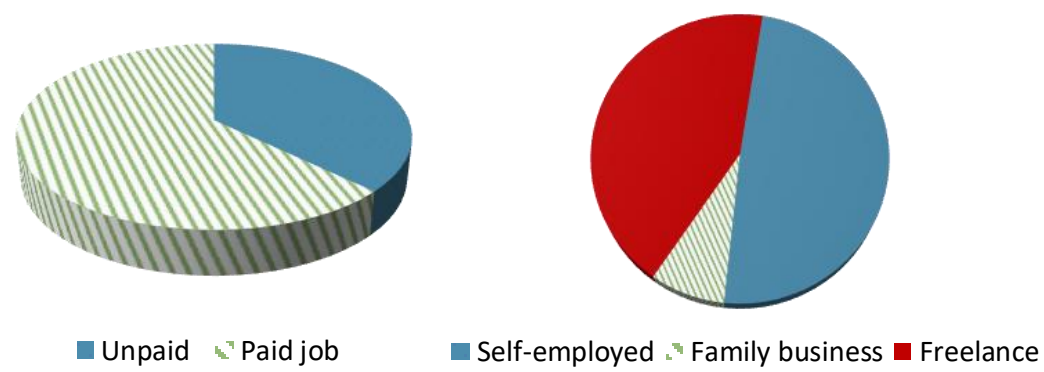

Source: DHS, DNB; and Fund staff estimates.

Differences in education levels and income between self-employed and employees in the DHS are worth noting. Akin to total population, the majority of self-employed has completed vocational education at high and intermediate level (Figure 3). However, compared to total population, the self-employed are proportionally more represented at university and high vocational education. In terms of gross income reported in the survey, about 35 percent of self-employed fall in the first quintile on the distribution, above the 20 percent recorded for the total working population. However, the top quintile comprises a similar share of workers across the two groups. On average, both groups plan to retire around age 66.

\footnotetext{
${ }^{6}$ The DHS is administered by CentERdata (Tilburg University, The Netherlands). The main questions on pensions and the range of available answers are reported in Appendix II.
} 


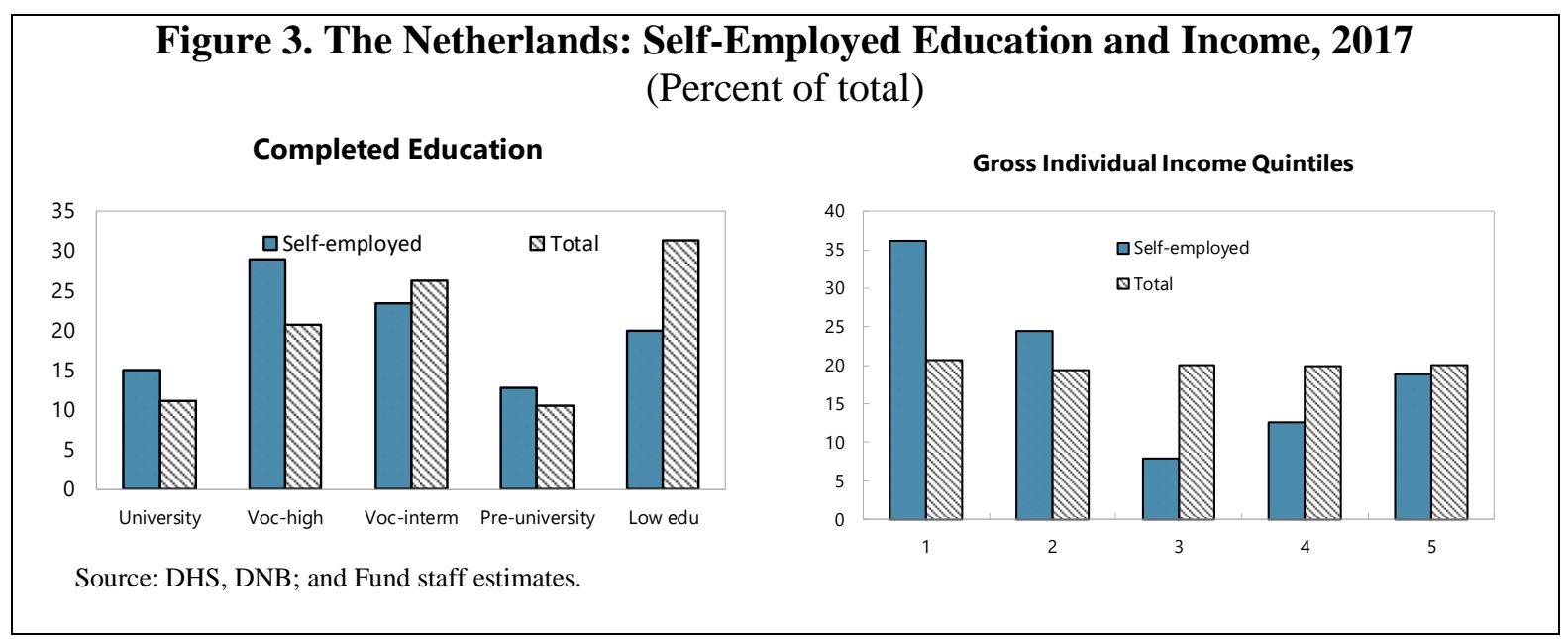

Self-employed participate in the pension system only marginally. A question in the DHS enquires about whether the respondents current or last job before retirement entitles him/her to a retirement pension (aside from the $1^{\text {st }}$ pillar, AOW, to which everyone is entitled). Only a fifth of self-employed answered affirmatively compared with 84 percent for the total surveyed employed population. Roughly the same share reports participating in one such plan offered by employers while only 11 percent of self-employed report having made other arrangements for their pension apart from the customary pension built through their employer either through annuities, whole life insurance policies, or additional pension rights purchased through the employer. This suggests that the majority of the self-employed are not covered by any formal pension arrangement though they may still be accumulating wealth in other ways. $^{7}$

Self-employed are less wellinformed about the pension system. Numerous studies find that information increases political support for reform (see for instance Boeri and Tabellini, 2012; Gouveia, 2017; van Dalen and Henkes, 2017). Parlevliet (2018) shows that respondents to the DHS have updated their preferences in favor of the increase in the retirement age in 2012 over time, possibly as a result of a learning process. Participants in the DHS are asked whether they feel adequately informed about their pensions. They are asked also whether they have received a prospectus from their pension fund in the past year (and which fund

\footnotetext{
${ }^{7} \mathrm{Li}$ and others (2016) report that only around 7 percent of self-employed in their sample were affiliated with the occupational pension system in 2010. Knoef and others (2017) show that self-employed build less wealth than employees through the $2^{\text {nd }}$ pillar, in particular at higher income levels, while their net replacement rates are lower.
} 
they belong to). Although a higher share of self-employed in the DHS feels well informed about the pension system, overall in the self-employed group fewer individuals feel well, more adequately or adequately informed and a higher share feels not adequately informed and uninterested in the pension system. The less-than-adequate information may be related to the employment status more directly, as self-employed may be more isolated from the key sources of communication including from pension funds. In fact, while two thirds of workers claim to have received an overview of pension rights from their fund in 2016 only about 40 percent of self-employed report the same.

Self-employed express a higher preference for freedom of choice in the management of their pension savings and are more willing to tolerate risk on their final pension income. Two key questions in the survey help us understand respondents attitudes towards the pension system: a question on savings management and a question on risk managemet. These questions are central to the study. Compared to total population, the self-employed more consistently opt for managing their savings independently, about 45 percent of the group. The remaining share is split between those who would gladly delegate savings decisions to a fund and those who would like to have a choice of the fund that manages their savings. This is in stark contracts with employees, about 65 percent of whom gladly delegate pension decisions to a fund (Figure 4). When asked whether they would rather pay more premium for a guaranteed pension or a lower premium for a pension that is on average expected to be equally high, but for which the final pension payment can vary depending on the investment risk selfemployed expressed a somewhat higher attitude towards risk taking, on average.

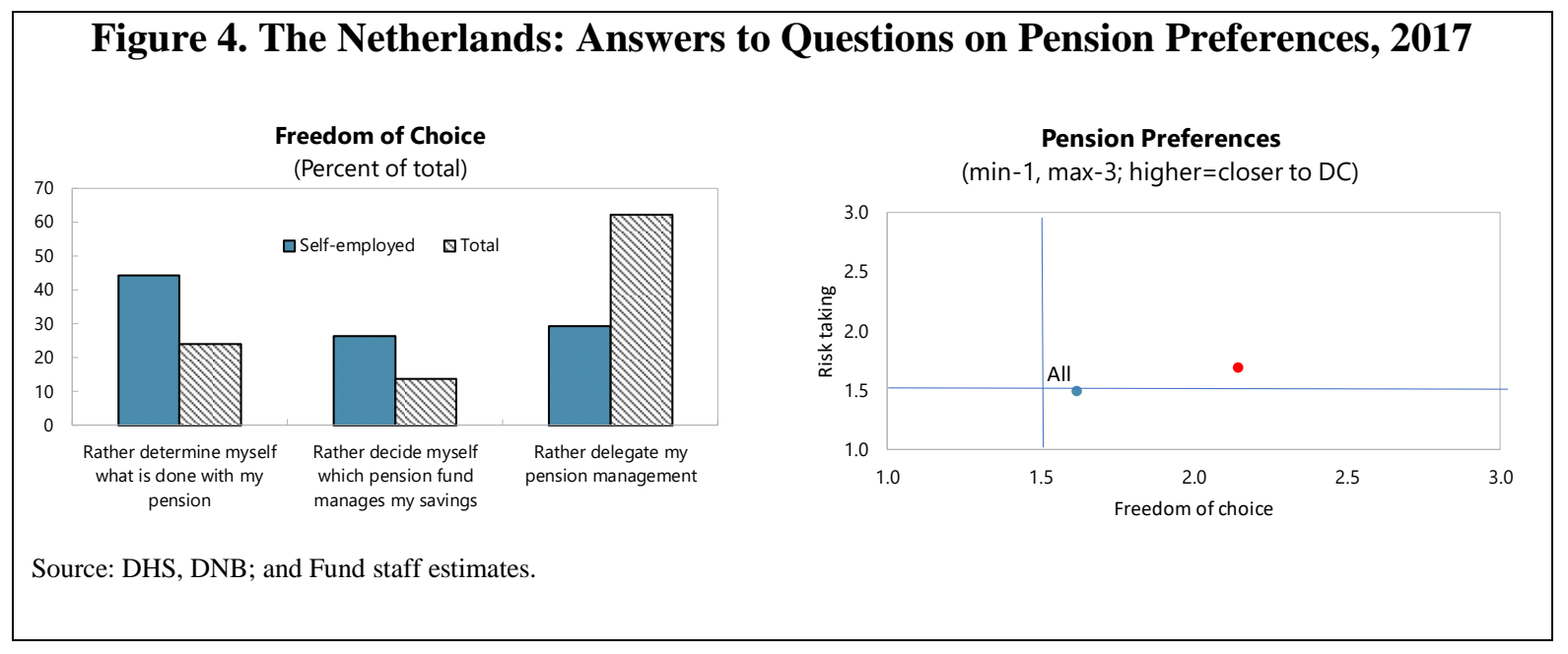

\section{Model Estimations}

The starting year for the panel is the one in which the current pension reform draft was initially proposed, and discussion with social partners launched. Thus, the panel comprises answers collected during the years 2014-17 for a total of about 20,000 observations. We are 
interested in gauging the probability of being self-employed given expressed preferences for greater freedom of choice and risk-taking, controlling for several observable and unobservable characteristics. We estimate the following model by means of a PROBIT regression: ${ }^{8}$

$$
S E_{i, t}=\alpha D C_{i, t}+\beta^{\prime} X_{i, t}+c_{t}+\varepsilon_{i, t}
$$

Where:

- The dependent variable, SE is a dummy that denotes the job status and takes the value of 1 if the individual is self-employed;

- The independent variables DC are dummies denoting two questions associated with pension system preferences. DC1 takes the value of 1 if the individual has indicated that he/she is willing to take a risk related to the pension income in exchange for paying a lower premium; DC2 is a dummy that takes the value of 1 if the respondent has expressed a preference for managing pension savings individually (as opposed to delegating it).

- $\quad X$ is a vector of demographic and psychological characteristics; and

- $\varepsilon$ is the error term.

\section{Definition of Key Variables}

\begin{tabular}{|llll|}
\hline Dummy variable & Abbreviation DHS code & Description \\
\hline Risk taking & DC1 & DNB95 & Value $=1$ if DNB95 $=2 ; 0$ otherwise \\
Freedom of choice & DC2 & DNB96 & Value $=1$ if DNB96 $=1 ; 0$ otherwise \\
Self-employed & SE & zelfst & Value $=1$ if zelfst $=1 ; 0$ otherwise \\
\hline
\end{tabular}

\section{A. Stylized Facts}

Personal characteristics can influence retirement income preferences and savings management, as well as the choice of contract type in many ways. ${ }^{9}$ The literature on the determinants of self-employment suggests that women are less likely to enter in this type of contract, among other reasons because they are intrinsically more risk averse. Age is found to have a positive influence on self-selection into self-employment, favored by accumulated social, individual and human capital through years and experience and stronger preference for flexibility. Self-employed are also more likely to be of older age when they have managed to build up sufficient savings and are less dependent on income from retirement. Individuals who have children may be more likely to be self-employed for a variety of reasons including flexibility to manage time, which helps preserve work-life balance, and pressure from increasing financial needs when the family is enlarged. On the other hand, risk aversion may increase. The theoretical literature and empirical evidence on the influence of

\footnotetext{
${ }^{8}$ See Appendix II for more detail on the construction of variables.

${ }^{9}$ See, for instance Simoes and others (2015), for an extensive review of literature.
} 
education on occupation status is ambiguous and suggests the relationship may be $\mathrm{U}$ shaped and obscured when employment industry is not taken into consideration. The relationship may go both ways because on the one hand more educated individuals can have better opportunities in contractual relationships while on the other hand, they can have better managerial abilities that make them succeed in self-employment. For what concerns income and wealth, individuals with higher income and those whose tax burden is higher may be more likely to be self-employed as in both cases their contributions would be lower. ${ }^{10}$ Moreover, individual with lower liquidity constraints may be more likely to star-up their own businesses with some initial capital.

Personality traits, also knows and non-cognitive abilities, may also affect occupational choice. An increasingly influential literature branch shows that individual personality traits are able to predict a variety of social and economic outcomes and affect preferences (Borghans and others, 2008; Almlund and others, 2011; Hudomiet and others, 2018). Risk attitudes, for instance, are predictive of investment decisions and entrepreneurship, and are associated with personality. Individuals do not necessarily maintain the same level of a trait over time, however, which can change as a result of exogenous shocks such as economic crises, or due to temporary changes in selfcontrol resources, emotions, or stress (Schildberg-Horisch, 2018). The DHS allows us to construct personal profiles based on a set of questions administered to respondents almost every year. Answers to psychological question in the DSH do not reveal stark differences across the two population groups with a slightly lower average score on "risk aversion" and higher on "patience" for the self-employed (Figure 5). The average score on "risk aversion" is the predominant trait across the entire surveyed population, with

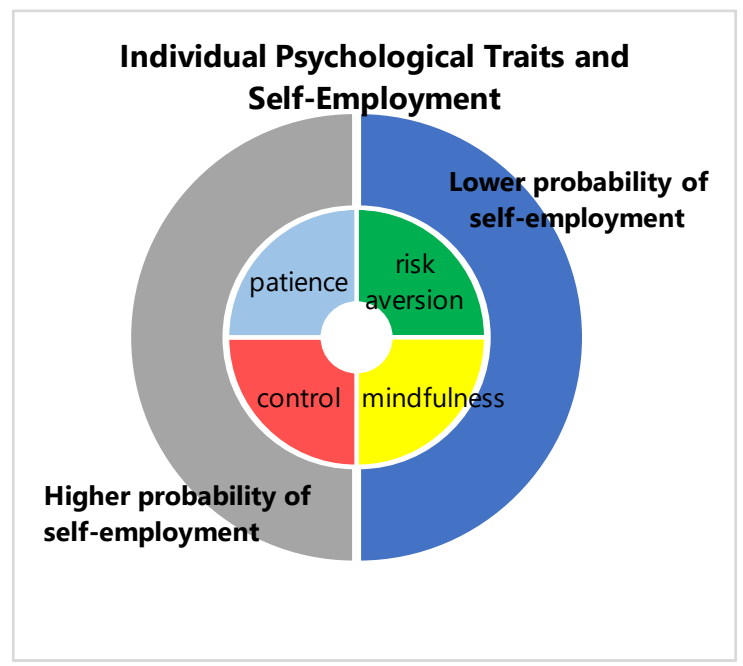
the average score of 5 in a range of 1 to 7 based on 6 questions. ${ }^{11}$ Based on literature, we expect that the probability of entry into self-employment is greater for individuals with lower levels of risk aversion. We also postulate that "patient" and "controlling" individuals are more likely to accept a self-employed status given that they are more likely to feel in charge of their working life and future income (+ sign) (Eren and Sula, 2012). Those "mindful" are less likely to do so (- sign) as self-employment is associated with higher but more uncertain income and less redistribution due to lower contributions.

\footnotetext{
${ }^{10}$ However, while income may suffer from endogeneity (the aggregate income variable includes retirement income), tax could display multicollinearity with income and employment status.

${ }^{11}$ See Appendix II for more detail.
} 


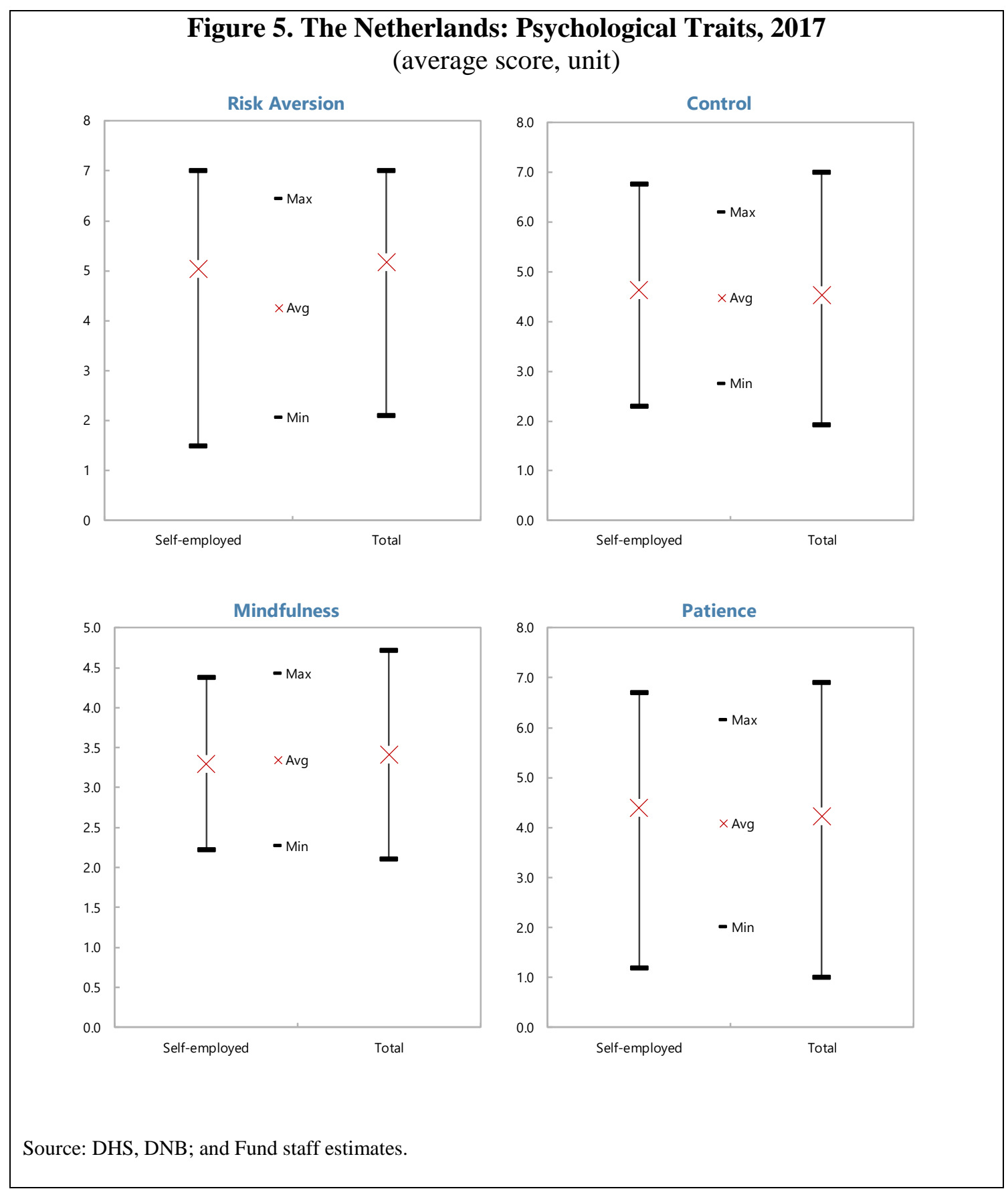




\section{Regression Results}

Individuals who prefer pension plans with more freedom of choice and more investment risk are significantly more likely to choose self-employment than regular employment. The regression shows that, given an expressed preference for "risk and choice", the probability of being self-employed is positive. The DC1 and DC2 dummies summarizing preference for freedom of choice and risk taking are significant and bear the expected sign. Self-employment, is also more likely at older ages, in line with findings in the literature, and at higher education levels. Interestingly, the reported perceived information level about future pension conditions which we include in the regression is not significant. Selfemployment is less likely when individuals pay higher taxes. This may be because self-employed have in general a lower tax burden being exempt from part of contributions. Psychological traits confirm expectations: self-employment is more probable when individuals feel in control of their life and savings and less common when they are mindful. Time dummies, gender, having children or not, civil status (not reported) and gross income are not significant in the estimation.

The findings suggest that pension system architecture in the Netherlands could be one of the determinants of individual employment choices. If the reform decreases pension wealth, or the perceived pension wealth, some individuals could find it necessary to increase savings including by spending more time in contractual employee relationships in response. This was true in the case of the 2006 reform that abolished preferential tax treatment of early retirement for certain groups and lowered the share of people willing to use their liquid assets for entrepreneurship, and thus self-employment (Mastrogiacomo and others, 2016). Moreover, a reform that introduces individual contracts which allow more flexibility should incentivize participation into the pension system and discourage self-employment.

\section{Reform Preferences and Self- Employment}

\begin{tabular}{|c|c|}
\hline \multicolumn{2}{|c|}{ Regression Results - PROBIT } \\
\hline Dependent var & SE \\
\hline DC1 & $\begin{array}{c}0.019 \text { * } \\
(0.010)\end{array}$ \\
\hline DC2 & $\begin{array}{l}0.036 \text { *** } \\
(0.010)\end{array}$ \\
\hline \multicolumn{2}{|l|}{ Age group (35-45) } \\
\hline$<35$ & $\begin{array}{l}-0.020 \\
(0.016)\end{array}$ \\
\hline $46-55$ & $\begin{array}{l}0.029 \text { ** } \\
(0.013)\end{array}$ \\
\hline $56-67$ & $\begin{array}{l}0.041^{* * *} \\
(0.013)\end{array}$ \\
\hline Gender (F) & $\begin{array}{r}0.015 \\
(0.010)\end{array}$ \\
\hline Gross income & $\begin{array}{r}0.000 \\
(0.000)\end{array}$ \\
\hline Tax burden & $\begin{array}{l}-0.020 * * \\
(0.008)\end{array}$ \\
\hline Children $(Y)$ & $\begin{array}{l}-0.012 \\
(0.010)\end{array}$ \\
\hline \multicolumn{2}{|c|}{ Education (primary and below) } \\
\hline Vocational_interm. & $\begin{array}{l}0.063 \text { *** } \\
(0.019)\end{array}$ \\
\hline Vocational_high & $\begin{array}{l}0.042 \text { ** } \\
(0.019)\end{array}$ \\
\hline Pre-university & $\begin{array}{l}0.046 \text { ** } \\
(0.022)\end{array}$ \\
\hline University & $\begin{array}{l}0.062 \text { *** } \\
(0.020)\end{array}$ \\
\hline Informed & $\begin{array}{r}0.002 \\
(0.004)\end{array}$ \\
\hline \multicolumn{2}{|l|}{ Psychological traits } \\
\hline Risk averse & $\begin{array}{r}-0.004 \\
(0.005)\end{array}$ \\
\hline Patient & $\begin{array}{l}-0.001 \\
(0.006)\end{array}$ \\
\hline Controlling & $\begin{array}{l}0.015 \text { ** } \\
(0.007)\end{array}$ \\
\hline Mindful & $\begin{array}{l}-0.030 * * * \\
(0.011)\end{array}$ \\
\hline N obs & 1,847 \\
\hline Pseudo R2 & 0.130 \\
\hline
\end{tabular}




\section{Conclusions}

The findings suggest that individuals who prefer pension plans with more freedom of choice and more investment risk are significantly more likely to choose self-employment as labor relationship. The choice to become self-employed may be influenced by a richer set of considerations than those captured in the model, including the preference for more flexibility in labor relations. However, favorable tax treatment inherent in self-employment has been one of the dominant reasons for the increase in flexible contracts in Netherlands over the past decade which was more pronounced among older workers and those with higher education levels. Self-employed participate only marginally in occupational pension schemes. In the DHS, self-employed have expressed a higher preference for freedom of choice in the management of pension savings and greater willingness to tolerate risk on final pension incomes. Mapping survey answers into pension reform support is not unequivocal and the current proposal, while broadly comparable to a transition toward a "plain" DC framework, is markedly complex. Despite possible limitations, after controlling for observable and unobservable individual characteristics, the link between self-employment and the support for greater individualization of savings plans appears strong. The analysis offers a starting point for shaping considerations surrounding the labor market effect of the pension reform.

Because of the complexity involved in managing new pension options, consensus and successful implementation may take time. The PPR-CB may indeed be the best of the two worlds in combining the most attractive features of both DB and DC plans while moving a step forward towards greater individualization. However, a reform that brings the system closer to the individual preferences and increases transparency would also increase complexity for pension system participants who did not have to take active interest in the management of retirement savings until now. The learning process may take time, as even individuals who prefer freedom of choice may not be ready to exercise it (van Dalen and Henkens, 2017). Meanwhile, maintaining trust in institution, which is currently at its highest in recent years, will be crucial for reaching a consensus and navigating the transition successfully (Figure 1, Appendix I). ${ }^{12}$

Greater transparency on the "missing arguments" would help build consensus and speed up reform implementation. The political economy literature offers numerous insights on options for overcoming reform resistance through elimination, compensation and information building (Tsebelis, 2000; Tsebelis and Hahm, 2014; Tompson and Price, 2009; James and Brooks, 2001). Though the literature on pension reform design is vast in the Netherlands, additional information in some areas could clarify remaining open questions and strengthen government's arguments. More specifically, the redistribution cost in the transition to the new contract type should be made explicit and the modalities of financing it specified. This

\footnotetext{
${ }^{12}$ Consumer confidence in the banking sector and employers is also high and rising (Banking Confidence Monitor 2017, The Dutch Banking Association; Statista 2018, The Edelman Trust Barometer, 2018).
} 
should clearly identify the losers and the winners of the reform, highlighting options for compensation in a wider reform package, acceptable to all parties.

\section{REFERENCES}

Almlund, M., A. L. Duckworth, J. J. Heckman, and T. Kautz., 2011, "Personality psychology and economics," in E. Hanushek, S. Machin, and L. Woessman (Eds.), Handbook of the Economics of Education, Volume 4, Chapter 1, pp. 1-181. Elsevier B.V.

Borghans, L., Duckworth, A., Heckman, J., and B. ter Weel, 2008, “The Economics and Psychology of Personality Traits," The Journal of Human Resources, XLIII, 4.

Bosch, N., de Graaf-Zijl, M., and D. van Vuuren, 2015, Position paper t.b.v. "IBO Zelfstandigen zonder personae”, CPB Notitie, The Hague: CPB Netherlands Bureau for Economic Policy Analysis.

Bovenberg, A. L., and T. Nijman, 2015, Personal Pensions with Risk Sharing: Affordable, Adequate and Stable Private Pensions in Europe, Nepstar Discussion Papers 03/2015005, Netspar, The Netherlands.

Bovenberg, A. L., and T. Nijman, 2017, New Dutch Pension Contracts and Lessons for Other Countries, Netspar Academic Series DP 09/2017-014, Netspar, The Netherlands.

Conen, W. and J. Schippers, 2017, "De Invloed van Startmotieven op de Financiële Situatie en Arbeidstevredenheid van Zzp'ers," Tijdschrift voor Arbeidsvraagstukken, 33(3): 250-268.

Dekker, F., Mevissen, J. and A. Oostveen, 2018, "Case Study-Gaps in Access to Social Protection for Self-employed Without Employees in the Netherlands," European Commission, Directorate-General for Employment Social Affairs and Inclusion.

DNBulletin, 2017, Pensioenfondsen Gaan in Herstelplannen uit van Hoge Rendementen.

European Commission, 2018, "Country Report the Netherlands 2018," SWD No. 217 (Brussels).

European Commission, 2018b, National Reform Programme 2018, The Netherlands (Brussels).

Eren, O. and O. Sula, 2012, “The Effect of Ability on Young Men's Self-Employment Decision: Evidence from the NELS," Industrial Relations, Volume 51, issue 4.

Gerard, M., 2019, "Reform Options for Mature Defined Benefit Pension Plans: The Case of the Netherlands," IMF Working Paper, WP/19/22, International Monetary Fund.

Gouveia, Ana F., 2017, "Political support for reforms of the pension system: two experiments," Journal of Pension Economics and Finance, Vol. 16, No. 03, pp. 371394. 
Government of the Netherlands, 2017, "Coalition Agreement 'Confidence in the Future",, Hague.

Hudomiet, P., Parker, A.M., and S. Rohwedder, 2018, "Cognitive Ability, Personality, and Pathways to Retirement: An Exploratory Study," in Work, Aging and Retirement, Volume 4, Issue 1, Pages 52-66.

James, E., and M. S. Brooks, 2001. "The Political Economy of Structural Pension Reform" in New Ideas About Old Age Security, (Washington: World Bank).

Josten, E., Vrooman, C. and J. Vlasblom, 2014, "Bevrijd of beklemd?”, The Hague: SCP.

Kalwij, A., A. Kapteyn, and K. de Vos, 2018, "Why Are People Working Longer in the Netherlands?," NBER Working Paper No. 24636.

Knoef, M., Been, J., Caminada, K., Goudswaard, K. and J. Rhuggenaath, 2017, “Adequacy of Pension Accrual After the Crisis and Pension Reforms," Netspar Industry Paper Series, DP 68/2017

Li,Y., Dillingh, R. and M. Mastrogiacomo, 2016, “The Displacement Effect of Compulsory Pension Savings on Private Savings: Evidence from the Netherlands Using Institutional Differences across Occupations," Netspar Academic Series, DP 08/2016025, The Netherlands.

Mastrogiacomo, M., Hochguertel, S. and H. Bloemen, 2016, "The Role of Wealth in the Start-up Decisions of new Self-Employed: Evidence from a Pension Policy Reform," Labour Economics, N. 41 (2016) 280-290, Elsevier.

Merkel, W., 2003, "Institutions and Reform Policy: Three Case Studies on the Veto Player Theory," Estudios-Working Paper, Vol. 2003/186.

Netspar, 2017, Pension in Transition, Annual Report 2017, Netspar, The Netherlands.

OECD, Economic Survey - Ecoscope, July 2018.

Parlevliet, J., 2017, "What drives public acceptance of reforms? Longitudinal evidence from a Dutch pension reform" Public Choice, Vol. 173, No. 1, pp. 1-23.

Ponds, E., and B. van Riel, 2007, "Sharing Risk: The Netherlands New Approach to Pensions," Number 2007-5, Center for Retirement Research, Boston College.

Preesman, L., 2017, "New Pensions System is Still a Long Way Off for the Netherlands," IPE Magazine, December

Simoes, N., Crespo, N., and S. Moreira, 2015, "Individual Determinants of Self-Employment Entry: What do We Really Know?," Journal of Economic Surveys, Volume 30, Issue 4.

Schildberg-Hörisch, H., 2018, “Are Risk Preferences Stable?,” Journal of Economic Perspectives-Volume 32, Number 2-Spring 2018-Pages 135-154.

Tsebelis, G., and H. Hahm, 2014, "Suspending Vetoes: How the Euro Countries Achieved Unanimity in the Fiscal Compact," Journal of European Public Policy, Vol. 21, No. 10, pp. 1388-1411. 
Tsebelis, G., 2000, "Veto Players and Institutional Analysis" Governance: An International Journal of Policy and Administration, Vol. 13, No. 4, pp. 441-474.

Tompson, W. and R. Price, 2009, "The Political Economy of Reform: Lessons from Pensions, Product Markets and Labour Markets in Ten OECD Countries" (Paris: OECD)

van Dalen, H. P., and K. Henkens, 2017, Do People Really Want Freedom of Choice? Assessing Preferences of Pension Fund Participants, Netspar Academic Series, DP 09/2017-016, Netspar, The Netherlands.

van der Cruijsen, C. and N. Jonker, 2016, "Pension Profile Preferences: The Influence of Trust and Expected Expenses," DNB Working Paper, No. 535, November 2016, De Netherlandische Bank.

Wills Tower Watson, 2018, "Evaluatie Wet Aanspasing Financieel Toetsingskader". 


\section{Appendix I. Data and Tables}

Table 1. The Netherlands: Key Parameters of the Dutch Pension System, 2018

\begin{tabular}{|c|c|c|c|}
\hline \multirow[b]{3}{*}{ Pension parameter } & \multicolumn{3}{|c|}{ Mandatory } \\
\hline & \multicolumn{2}{|c|}{ 1st pillar } & \multirow{2}{*}{$\begin{array}{c}\text { 2nd pillar } \\
\text { Occupational }\end{array}$} \\
\hline & Minimum pension & $\begin{array}{l}\text { Disability and } \\
\text { survivors benefit }\end{array}$ & \\
\hline Provider & Public & Public & Private \\
\hline Coverage & $\begin{array}{l}\text { All residents (not } \\
\text { means tested) }\end{array}$ & & $90 \%$ active workers \\
\hline Funding & DB/PAYG & DB/PAYG & Hybrid DB \\
\hline Pensionable age & $\begin{array}{l}\text { Increasing to } 67 \text { by } \\
2021 \text {, then linked } \\
\text { to life expentancy }\end{array}$ & & 68 in 2018 \\
\hline \multicolumn{4}{|l|}{ Beneficiaries } \\
\hline Millions (2016) & \multicolumn{3}{|c|}{4.04} \\
\hline Benefit formula & & & average of all salaries \\
\hline Accrual rate, annual & & & 1.875 \\
\hline \multicolumn{4}{|l|}{ Annual benefit per person, gross } \\
\hline Maximum (in eur, 2017) & & & 103,317 \\
\hline Average (in eur, 2017) & & & 14,737 \\
\hline \multicolumn{4}{|l|}{ Percent of GDP per capita } \\
\hline \multicolumn{4}{|l|}{ Expenditure (2016) } \\
\hline Billions eur & 37.5 & 13.5 & 41.1 \\
\hline Percent of GDP & 5.3 & 1.9 & 5.8 \\
\hline Indexation post-retirement & minimum wages & & $\mathrm{CPI}$ \\
\hline \multicolumn{4}{|l|}{ Contributions (2016) } \\
\hline Contributors (millions) & \multirow{2}{*}{\multicolumn{2}{|c|}{ the AOW franchise }} & \\
\hline Contribution rate (average) & & & employers 17 , workers 7 \\
\hline Contributions (gross, billions) & \multicolumn{2}{|c|}{49.6} & 31.2 \\
\hline Percent of GDP & \multicolumn{2}{|c|}{7.0} & 4.4 \\
\hline \multicolumn{4}{|c|}{ Interest rate on contributions (monthly, Dec 2017) } \\
\hline \multicolumn{4}{|l|}{ Size of fund (in 2017) } \\
\hline Billions eur & & & 1620 \\
\hline Percent of GDP & & & 220 \\
\hline Non-indexed funding ratio (2017) & & & 103/105 (regulatory $\mathrm{min}$ ) \\
\hline
\end{tabular}

Figure 1. The Netherlands: Trust in Institutions, 2000-18
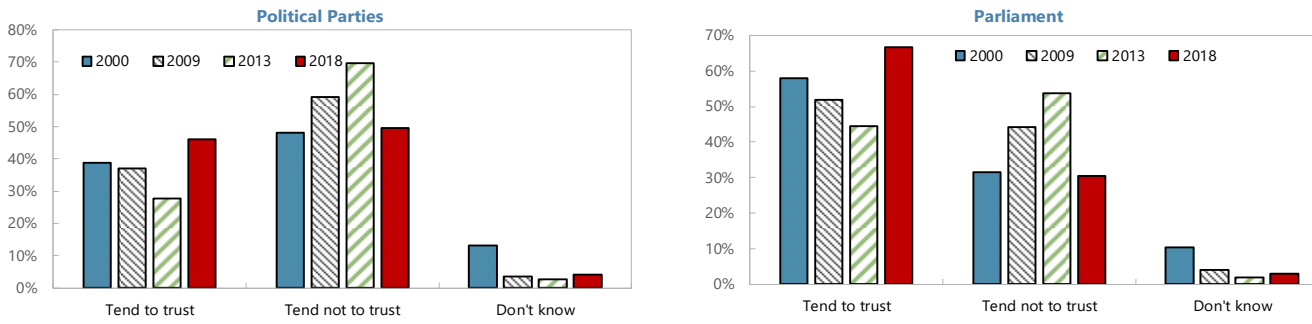

Government
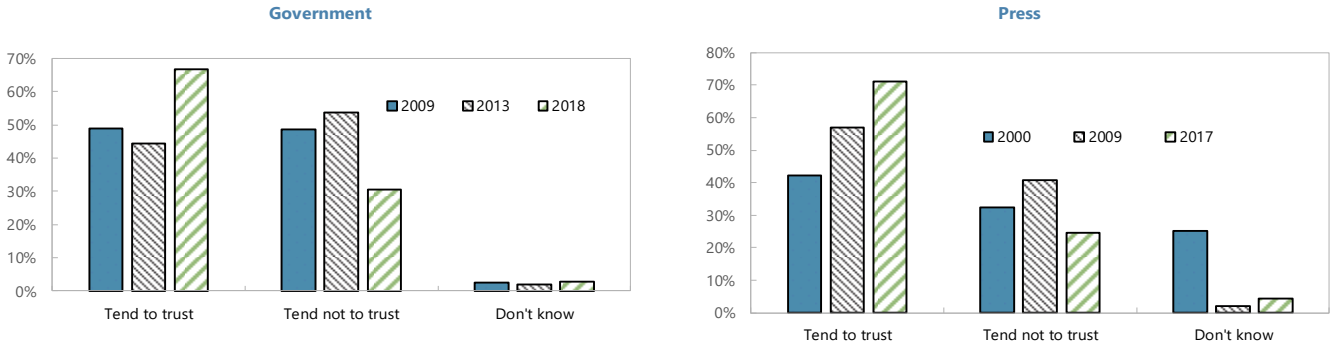


\section{Appendix II. The DNB Households Survey (DHS)}

\section{Variables Description}

- The dependent variables DC1 and DC2 are constructed from the responses reported in variables dnb95 and dnb96 in the survey. DC1 takes the value of 1 if the individual has indicated that he/she is willing to take a risk related to the pension income in exchange for paying a lower premium; DC2 is a dummy that takes the value of 1 if the respondent has expressed a preference for managing pension savings individually.

- The variable age is constructed from the variable birth less the year of the survey. It is used to construct 5 dummies for the main age groups. Individuals who are older than 67 are dropped from the estimation.

- The educational dummies reflect completed education level of respondents which is grouped into "low" if the respondent has completed primary education or below or special education (a limited number of individuals in the survey report it). Other dummies encompass university, pre-university and vocational education at high and intermediate level.

- Female is a gender dummy that takes the value of 1 if the respondent is female.

- Children is a dummy variable indicating that the respondent reported having children when the value is 1 .

- Married is a dummy which takes the value of 1 if the individual lives in a registered partnership and 0 if the individual is divorced, living in an unregistered partnership, widowed or has never been married.

- Health is a step dummy indicating the self-reported health status of the individual. It takes the value of 1 if the reported health status is excellent, 2 if good, 3 if fair, 4 if not so good, and 5 if poor.

- Informed is a step dummy variable taking the value of 1 to 6 depending on how informed the individual feels about his/her future pension arrangements. A lower value is associated with feeling better informed.

- The variable tax is the implied overall tax burden, calculated as a difference between gross and net income and divided by the net income. We also use the variable income tax $\mathrm{ib}$ - calculated based on the taxable components of the total gross income and includes the social security premiums - to construct an alternative measure of tax burden.

- Total gross and the total net income - btot and ntot - are calculated based on a large number of reported sources of income on a personal level. They include all forms of 
income: from work, benefits (social assistance and social insurance), scholarships, tax credit, rental etc.

- Employment status dummies:

Employee takes the value of 1 if the individual is employed on a contractual basis or works in own business.

Self-employed takes the value of 1 if the individual is self-employed, freelancer or in a free profession and 0 otherwise.

Unemployed takes the value of 1 if the individual is looking for a job after having lost one or looking for the first job.

Other work takes the value of 1 if the individual performs households, voluntary, unpaid, or other work, is not a student, retiree, employee or self-employed.

- Psychological traits variables: respondents in the survey are asked to express agreement over statements on their personality on a scale of 1 to 7 (from extremely uncharacteristic to extremely characteristic). Coverage and the number of questions may vary across years.

Risk averse - mean of values (between 1 and 7) associated to answers on 6 questions depicting personal traits linked to risk aversion.

Patient - mean of values (between 1 and 7) associated to answers on 12 questions depicting personal traits linked to patience.

Controlling - mean of values (between 1 and 7) associated to answers on 13 questions depicting personal traits linked to locus of control.

Mindful - mean of values (between 1 and 5) associated to answers on 18 questions depicting personal traits linked to consciousness.

In some instances, the values needed to be recoded and missing variables in certain years replaced with average responses from previous years. 


\section{DHS Questions on Pensions}

(dnb94)

\section{Which of the below mentioned statements applies to you most?}

1. I do not worry about my pension arrangements, we'll see by then.

2. It is important to know that my pension is taken care of, without knowing the details.

3. I keep well informed about any developments regarding my pension.

4. I don't know.

(dnb95)

Which of the below mentioned statements applies to you most?

1. I'd I rather pay more premium for a guaranteed pension (money for pension mainly invested in bonds).

2. I'd rather pay less premium for a pension that on average is equally high or is expected to be equally high, but for which the final pension payment can be higher or lower due to the higher risk of the chosen investment form (money for pension mainly invested in stocks).

3. I don't know.

(dnb96)

Which of the below mentioned statements applies to you most?

1. I'd rather determine myself what is done with the pension premiums I pay, so that the final pension payment depends on the decisions I made.

2. I'd rather decide which pension fund manages my pension premiums for me.

3. Building up my pension I gladly leave to the pension fund of my employer.

4. Not applicable.

5. I don't know.

(dnb207a)

In 2012, it has been decided to increase the general old-age pension age. To make sure that the general old-age pension remains affordable, which of the following measures appeals to you most?

1. A lower general old-age pension.

2. An increase of the old-age pension premium for people working.

3. Increase the age on which I will receive the general old-age pension. 
(dnb207b)

Which of the two remaining measures appeals the most to you thereafter?

1. A lower general old-age pension.

2. An increase of the old-age pension premium for people working.

3. Increase the age by two years on which I will receive the general old-age pension.

(dnb116)

Will you adjust your conduct if the pensions are cut down, for example through an adjustment on the indexation, postponement of the retirement age or a different pension system?

1. Yes, I will put more money aside for my pension.

2. No, I will see what I'll do when it happens.

3. No, I think I can make ends meet fairly easily with the pension I will have.

4. Other.

5. I don't know.

(dnb210)

Suppose your pension fund makes a choice between increasing the pension premium or increase the risk of the investment, as a result of which the exact amount of your pension becomes less certain (there is a $2.5 \%$ chance that it will be $10 \%$ lower). Will you change your savings behavior if the fund chooses an investment mix with a higher risk but the premium remains the same?

1. Yes, I will put more money aside towards my pension.

2. No, I will see what I'll do when it happens.

3. No, I think I can make ends meet fairly easily with the pension I will have.

4. Other.

5. I don't know. 